\title{
Approaches to Improve the Pharmacokinetics of Radiolabeled Glucagon-Like Peptide-1 Receptor Ligands Using Antagonistic Tracers
}

\author{
Svetlana N. Rylova ${ }^{1-3}$, Beatrice Waser ${ }^{4}$, Luigi Del Pozzo ${ }^{1-3}$, Roswitha Tönnesmann², Rosalba Mansi², Philipp T. Meyer ${ }^{2}$, \\ Jean Claude Reubi ${ }^{4}$, and Helmut R. Maecke ${ }^{2}$ \\ ${ }^{I}$ German Cancer Consortium (DKTK), Heidelberg, Germany; ${ }^{2}$ Department of Nuclear Medicine, Medical Center - University of \\ Freiburg, Faculty of Medicine, University of Freiburg, Freiburg, Germany; ${ }^{3}$ German Cancer Research Center (DKFZ), Heidelberg, \\ Germany; and ${ }^{4}$ Institute of Pathology, University of Berne, Berne, Switzerland
}

The glucagon-like peptide-1 (GLP-1) receptors are important biomarkers for imaging pancreatic $\beta$-cell mass and detection of benign insulinomas. Using GLP-1 receptor antagonists, we aimed to eliminate the insulin-related side effects reported for all GLP-1 receptor agonists. Additionally, using a nonresidualizing tracer, 125 -BoltonHunter-Exendin(9-39) $\mathrm{NH}_{2}$ ( ${ }^{125} \mathrm{I}-\mathrm{BH}-\mathrm{Ex}(9-39) \mathrm{NH}_{2}$ ), we aimed to reduce the high kidney uptake, enabling a better detection of insulinomas in the tail and head of the pancreas. Methods: The affinity and biodistribution of Ex(9-39) $\mathrm{NH}_{2}$-based antagonists, modified with DOTA or NODAGA chelators at positions Lys $^{27}$ and Lys ${ }^{40}$ and labeled with ${ }^{68} \mathrm{Ga}$ and ${ }^{125} \mathrm{I}-\mathrm{BH}-\mathrm{Ex}(9-39) \mathrm{NH}_{2}$, were compared with the reference GLP-1 receptor agonist $\left[\mathrm{Nle}^{14}{ }^{1} \mathrm{Lys}^{40}\left(\mathrm{Ahx}-\mathrm{DOTA}-{ }^{68} \mathrm{Ga}\right) \mathrm{NH}_{2}\right] \mathrm{Ex}-4$. The inhibitory concentration of $50 \%\left(\mathrm{IC}_{50}\right)$ values were determined using autoradiography on human tissues with ${ }^{125}$ I-GLP-1(7-36) $\mathrm{NH}_{2}$ as a radioligand. Pharmacokinetics and PET imaging were studied in nude mice bearing rat Ins-1E tumors. Results: Conjugation of DOTA and NODAGA chelators at positions Lys ${ }^{27}$ and Lys ${ }^{40}$ of $\operatorname{Ex}(9-39) \mathrm{NH}_{2}$ resulted in a distinct loss of affinity toward GLP-1 receptor in vitro. Among the studied antagonists, [Lys ${ }^{40}$ (NODAGA-nat Ga) $\mathrm{NH}_{2}$ ] Ex(9-39) showed the lowest $I_{50}$ value $(46.7 \pm 16.3 \mathrm{nM})$. The reference agonist $\left[\mathrm{Nle}^{14}{ }^{14} \mathrm{Lys}^{40}(\mathrm{Ahx}-\mathrm{DOTA}) \mathrm{NH}_{2}\right] \mathrm{Ex}-4$ demonstrated the highest affinity $\left(\mathrm{IC}_{50}=0.9 \pm 0.3 \mathrm{nM}\right)$. Biodistribution of $\left[\mathrm{Nle}^{14}\right.$, Lys ${ }^{40}(\mathrm{Ahx}-$ DOTA- $\left.{ }^{68} \mathrm{Ga}\right) \mathrm{NH}_{2}$ ] Ex-4 at $1 \mathrm{~h}$ after injection demonstrated $40.2 \pm$ 8.2 percentage injected activity per gram $(\% \mathrm{IAg})$ uptake in Ins-1E tumor, $12.5 \pm 2.2 \% \mathrm{IAg}$ in the pancreas, and $235.8 \pm 17.0 \% \mathrm{IAV}$ in the kidney, with tumor-to-blood and tumor-to-kidney ratios of 100.52 and 0.17 , respectively. Biodistribution of [Lys $\left.{ }^{40}(\mathrm{NODAGA}-68 \mathrm{Ga}) \mathrm{NH}_{2}\right] \mathrm{Ex}(9-39)$ showed only $2.2 \pm 0.2 \% \mathrm{IAVg}$ uptake in Ins-1E tumor, $1.0 \pm 0.1 \% \mathrm{IA} / \mathrm{g}$ in the pancreas, and $78.4 \pm 8.5 \% \mathrm{IA} / \mathrm{g}$ in the kidney at $1 \mathrm{~h}$ after injection, with tumor-to-blood and tumor-to-kidney ratios of 7.33 and 0.03 , respectively. In contrast, ${ }^{125}$-BH-Ex(9-39) $\mathrm{NH}_{2}$ showed tumor uptake $(42.5 \pm 8.1 \% \mathrm{IA} / \mathrm{g})$ comparable to the agonist and $28.8 \pm 5.1$ $\% \mathrm{IAV}$ in the pancreas at $1 \mathrm{~h}$ after injection. As we hypothesized, the kidney uptake of ${ }^{125}$ - $\mathrm{BH}-\mathrm{Ex}(9-39) \mathrm{NH}_{2}$ was low, only $12.1 \pm 1.4 \% \mathrm{IA} / \mathrm{g}$ at $1 \mathrm{~h}$ after injection. The tumor-to-kidney ratio of ${ }^{125}$ I-BH-Ex(9-39) $\mathrm{NH}_{2}$ was improved 20-fold. Conclusion: Our results suggest that iodinated $\operatorname{Ex}(9-39) \mathrm{NH}_{2}$ may be a promising tracer for imaging GLP-1 receptor expression in vivo. Because of the 20 -fold improved tumorto-kidney ratio ${ }^{125}$ I- $\mathrm{BH}-\mathrm{Ex}(9-39) \mathrm{NH}_{2}$ may offer higher sensitivity in the

Received Oct. 27, 2015; revision accepted Mar. 21, 2016.

For correspondence or reprints contact: Svetlana N. Rylova, Department of Nuclear Medicine, University Hospital Freiburg, Hugstetterstrasse 55, D-79106, Freiburg, Germany.

E-mail: svetlana.rylova@uniklinik-freiburg.de

Published online Apr. 28, 2016.

COPYRIGHT $\odot 2016$ by the Society of Nuclear Medicine and Molecular Imaging, Inc. detection of insulinomas and imaging of $\beta$-cell mass in diabetic patients. Further studies with ${ }^{124} \mathrm{I}-\mathrm{BH}-\mathrm{Ex}(9-39) \mathrm{NH}_{2}$ are warranted.

Key Words: GLP-1 receptor; insulinoma; $\beta$-cell mass; antagonist

J Nucl Med 2016; 57:1282-1288

DOI: $10.2967 /$ jnumed.115.168948

$\mathbf{T}$ he glucagon-like peptide (GLP-1) receptors are important targets because they are overexpressed on more than $90 \%$ of benign insulinomas, some malignant insulinomas, most gastrinomas, and most phaeochromocytomas (1). Physiologically they are also expressed in the endocrine pancreas. Preoperative imaging of insulinomas is critical, because it helps to precisely localize these often very small lesions in the pancreas. Therefore, imaging probes for optical (2), bimodal (3), SPECT (4-7), and PET (813) imaging as well as MRI (14) were developed to localize GLP1 receptors preoperatively and in addition to determine $\beta$-cell mass in diabetic animal models and potentially in patients. In particular, SPECT $(4,5,7)$ and PET $(8,13,15)$ agents were successfully translated into the clinic, and several promising clinical studies were reported. Still, there are a few shortcomings with the available tracers. The tracers accumulate highly in the kidneys when residualizing radiometals are used for labeling, possibly leading to not only unnecessary high radiation doses but also problems in localizing tumors in the tail and head of the pancreas $(5,8,13)$. The usually low specific activity of the imaging tracers, exclusively agonists, and the concomitant relatively high peptide mass lead to insulin release followed by hypoglycemia.

To solve the problem with agonist-induced side effects, we hypothesized that using radiolabeled antagonists is a promising strategy. Indeed, looking at other G-protein-coupled receptors such as the somatostatin (16) and gastrin-releasing peptide $(17,18)$ receptor families, radiolabeled antagonists are better imaging agents with higher tumor uptake and longer tumor retention time. In addition, no side effects such as cramps or vomiting were encountered when bombesin-based antagonists were used, in contrast to when radioagonists were used $(18,19)$.

Exendin(9-39)-amide isolated from Heloderma suspectum venom has been reported to be a GLP-1 receptor-specific antagonist (20), and the ${ }^{125}$ I-Bolton-Hunter-conjugated $\operatorname{Ex}(9-39) \mathrm{NH}_{2}$ was shown to target rat pancreatic islets in vivo (21). In addition, 
Brom et al. showed that the antagonist [Lys ${ }^{40}\left(\mathrm{DTPA}-{ }^{111} \mathrm{In}\right) \mathrm{NH}_{2}$ ] Ex(9-39) was an inferior imaging agent (6). We were intrigued by data from Waser et al. (22) showing that for ${ }^{125}$ I-Bolton-Hunterlabeled $\operatorname{Ex}(9-39) \mathrm{NH}_{2}$ it is of utmost importance at what position the peptide is modified. Lys $^{27}$ was identified as the only position to result in an ${ }^{125}$ I-labeled agent that showed the same performance in human tissue binding assays as the potent agonist ${ }^{125}$ I-GLP-1(736) $\mathrm{NH}_{2}$ (22). We therefore hypothesized that modification at $\mathrm{Lys}^{27}$ with chelates may lead to more potent radiometal-labeled GLP-1 receptor antagonists than the modification at $\mathrm{Lys}^{40}$.

To overcome the high kidney uptake, we hypothesized that the use of iodinated peptides may be advantageous. Radioiodine belongs to the no-residualizing labels and will not be retained in the kidney after reabsorption and degradation in the proximal tubular cells (23-25). Therefore, we compared the performance of $\operatorname{Ex}(9-39) \mathrm{NH}_{2}$ antagonists, conjugated to chelates at positions $\mathrm{Lys}^{27}$ and Lys ${ }^{40}$ with $\left[\mathrm{Nle}^{14}{ }^{4} \mathrm{Lys}^{40}\right.$ (Ahx-DOTA- ${ }^{68} \mathrm{Ga}$ ) NH $\mathrm{NH}_{2}$ ]Ex-4, a clinically used GLP-1 receptor agonist (15). Additionally, we evaluated in vivo the $\left[{ }^{125} \mathrm{I}-\right.$ BH-Lys $\left.{ }^{27}\right] \operatorname{Ex}(9-39) \mathrm{NH}_{2}$ conjugate as a surrogate of the ${ }^{124} \mathrm{I} /{ }^{131} \mathrm{I}-$ labeled $\operatorname{Ex}(9-39) \mathrm{NH}_{2}$ derivative.

\section{MATERIALS AND METHODS}

\section{Animal Model}

All animal experiments were conducted in accordance with the German animal protection law (TierSchG). The protocol was approved by the Animal Welfare Ethics committees of the University of Freiburg (Regierungspraesidium Freiburg Az G-12/21).

Female BALB/c nude mice (weight, 18-20 g; age, 6-8 wk) were obtained from Janvier Labs and were housed and handled in accordance with the good animal practice as defined by FELASA and the national animal welfare body GVSOLAS. Xenografts were established on the right shoulder by subcutaneous injection of 5 million rat Ins-1E cells $(26)$ in $1: 1 \mathrm{v} / \mathrm{v}$ mixture of phosphate-buffered saline and Matrigel (final volume, $100 \mu \mathrm{L}$ ) under isoflurane anesthesia. Mice were fed $60 \%$ Glucose Diet (PROVIMI KLIBA SA).

\section{Peptides and Radiochemistry}

The following structures of the peptides $\left[\mathrm{Nle}^{14}, \mathrm{Lys}^{40}(\mathrm{Ahx}-\mathrm{DOTA}) \mathrm{NH}_{2}\right]$ Ex-4, [Lys ${ }^{27}$ (Ahx-DOTA)]Ex(9-39) $\mathrm{NH}_{2}$, [Lys ${ }^{27}$ (NODAGA) $] \operatorname{Ex}(9-39) \mathrm{NH}_{2}$, and $\left[\mathrm{Lys}^{40}(\mathrm{NODAGA}) \mathrm{NH}_{2}\right] \operatorname{Ex}(9-39)$ were designed by Svetlana $\mathrm{N}$. Rylova and Helmut R. Maecke and custom-synthesized by Peptide Specialty Laboratories. The purity was analyzed using analytic reversed-phase high-performance liquid chromatography on an analytic 120-5 C18 Nucleosil column, with a linear gradient of $15 \%-90 \%$ solvent $\mathrm{B}$ in $25 \mathrm{~min}$ at a flow rate of $1 \mathrm{~mL} / \mathrm{min}$ (solvent $\mathrm{A}, 0.1 \%$ trifluoroacetic acid/H2O; solvent $\mathrm{B}, 0.1 \%$ trifluoroacetic acid/acetonitrile). The ${ }^{\text {nat }} \mathrm{Ga}$ complexation was performed as recently published (27), and ${ }^{125} \mathrm{I}-\mathrm{BH}-\mathrm{Ex}(9-39) \mathrm{NH}_{2}$ (specific activity, $81.4 \mathrm{MBq} / \mathrm{nmol}$ ) was purchased from Perkin-Elmer. $\mathrm{Ex}(9-39) \mathrm{NH}_{2}$ was purchased from Bachem. Mass spectrometry analysis was performed on an Ultraflex TOFTOF I instrument (Bruker Daltonik GmbH). Radiolabeling with ${ }^{68} \mathrm{Ga}$ was conducted using a ${ }^{68} \mathrm{Ge} /{ }^{68} \mathrm{Ga}$ generator IGG100 (Eckert and Ziegler) and Modular-Lab PharmTracer module (Eckert and Ziegler) essentially as described previously (28).

\section{Biodistribution Studies}

Ins-1E tumor-bearing mice were randomized after the tumor sizes had reached approximately $100 \mathrm{mg} .{ }^{68} \mathrm{Ga}$-labeled tracers $(100 \mathrm{pmol}$; $0.4-0.9 \mathrm{MBq})$ or ${ }^{125} \mathrm{I}-\mathrm{BH}-\mathrm{Ex}(9-39) \mathrm{NH}_{2}(0.037 \mathrm{MBq})$ in $100 \mu \mathrm{L}$ of sterile saline were administered via intravenous tail injection. For blocking experiments, animals were injected (intravenously) with $80 \mathrm{nmol}$ of $\operatorname{Ex}(9-39) \mathrm{NH}_{2}$ at $5 \mathrm{~min}$ before administration of the radiolabeled peptide. At 1,4 , and $24 \mathrm{~h}$ after radiotracer administration, animals ( $n=3-4$, per group) were euthanized by asphyxiation with excess isoflurane, and tissues were removed, rinsed in water, dried in air, weighed, and counted on a calibrated and normalized $\gamma$-counter for accumulation of radioactivity.

\section{Small-Animal PET/CT Imaging}

Ins-1E-bearing mice were administered 100 pmol $(0.4-0.9 \mathrm{MBq})$ of $\left[\mathrm{Nle}^{14}{ }^{\mathrm{Lys}}{ }^{40}\left(\mathrm{Ahx}-\mathrm{DOTA}-{ }^{68} \mathrm{Ga}\right) \mathrm{NH}_{2}\right] \mathrm{Ex}-4$ or $\left[\mathrm{Lys}^{40}\left(\mathrm{NODAGA}-{ }^{68} \mathrm{Ga}^{4} \mathrm{NH}_{2}\right] \mathrm{Ex}\right.$ (9-39) in $100 \mu \mathrm{L}$ of sterile saline via intravenous injection. One hour after injection, mice were euthanized, and 20- to 40-min static scans were acquired using a microPET Focus 120 scanner (Concorde Microsystems), followed by 2-min CT scans on a micro-CT-Tomoscope Synergy system (CT Imaging $\mathrm{GmbH}$ ).

\section{Inhibitory Concentration of $\mathbf{5 0 \%}\left(\mathrm{IC}_{50}\right)$ Determination and Autoradiography}

$\mathrm{IC}_{50}$ values were measured using in vitro receptor autoradiography on frozen sections of human insulinomas and frozen Ins-1E cell pellets with ${ }^{125} \mathrm{I}-\mathrm{GLP}-1(7-36) \mathrm{NH}_{2}$ as a radioligand, essentially as described previously (1). For ex vivo digital autoradiography, tumors were fast-frozen on dry ice and embedded in optimum-cutting-temperature compound, and then $10-\mu \mathrm{m}$ sections were cut using a Leica CM1950 cryomicrotome. Sections were exposed on a Super Resolution phosphor screen (Perkin Elmer) for $7 \mathrm{~d}$. The digital autoradiography images were obtained by scanning the phosphor screens on the Cyclone Plus Phosphor Imager (Perkin Elmer). Adjacent 10- $\mu \mathrm{m}$ slices were stained with hematoxylin and eosin and scanned using Panoramic SCAN 150 (3D Histech).

\section{Statistical Analysis}

Data and statistical analyses were performed using GraphPad Prism 5.01 (GraphPad Software, Inc.) and Microsoft Excel. Data were analyzed using the unpaired, 2-tailed Student $t$ test. Differences at the 95\% confidence level $(P<0.05)$ were considered to be statistically significant.

\section{RESULTS}

\section{Radiolabeling Procedures}

Peptides were radiolabeled with ${ }^{68} \mathrm{Ga}$ using a ${ }^{68} \mathrm{Ga} / \mathrm{Ge}$ generator with a radiochemical purity of more than $98 \%$ and specific activity of $15.2 \mathrm{MBq} / \mathrm{nmol}$ for $\left[\mathrm{Lys}^{27}\left(\mathrm{Ahx}-\mathrm{DOTA}-{ }^{68} \mathrm{Ga}\right)\right] \mathrm{Ex}(9-39) \mathrm{NH}_{2}$, $10.3 \mathrm{MBq} / \mathrm{nmol}$ for $\left[\mathrm{Lys}^{40}\left(\mathrm{NODAGA}-{ }^{68} \mathrm{Ga}\right) \mathrm{NH}_{2}\right] \mathrm{Ex}(9-39)$ and $\left[\mathrm{Lys}^{27}\left(\mathrm{NODAGA}-{ }^{68} \mathrm{Ga}\right)\right]-\mathrm{Ex}(9-39) \mathrm{NH}_{2}$, and $10.1 \mathrm{MBq} / \mathrm{nmol}$ for $\left[\mathrm{Nle}^{14}, \mathrm{Lys}^{40}\left(\mathrm{Ahx}-\mathrm{DOTA}-{ }^{68} \mathrm{Ga}\right) \mathrm{NH}_{2}\right] \mathrm{Ex}-4$.

\section{Binding Affinities of Ex(9-39)-Based Tracers}

Autoradiographic studies with ${ }^{125} \mathrm{I}-\mathrm{GLP}-1(7-36) \mathrm{NH}_{2}$ as a radioligand were used to determine $\mathrm{IC}_{50}$ values for the human GLP-1 (hGLP-1) receptor (Table 1). Naturally occurring GLP-1 receptor agonist GLP-1(7-36) $\mathrm{NH}_{2}$ was used as an internal reference, and agonist $\left[\mathrm{Nle}^{14}, \mathrm{Lys}^{40}\left(\mathrm{Ahx}-\mathrm{DOTA}-{ }^{68} \mathrm{Ga}\right) \mathrm{NH}_{2}\right] \mathrm{Ex}-4$, validated for insulinoma imaging in patients (15), was used as a reference for biodistribution studies (Table 1 ). The lowest $\mathrm{IC}_{50}$ values were found for the 2 agonists $\left[\mathrm{Nle}^{14}, \mathrm{Lys}^{40}(\mathrm{Ahx}-\mathrm{DOTA}) \mathrm{NH}_{2}\right] \mathrm{Ex}-4(0.9 \pm$ $0.3 \mathrm{nmol} / \mathrm{L})$ and GLP-1(7-36) $\mathrm{NH}_{2}(1.1 \pm 0.3 \mathrm{nmol} / \mathrm{L})$. The unmodified antagonist $\operatorname{Ex}(9-39) \mathrm{NH}_{2}$ showed relatively high affinity for hGLP-1 receptor $(10.9 \pm 1.1 \mathrm{nmol} / \mathrm{L})$, but on conjugation of a DOTA chelator at positions $\mathrm{Lys}^{27}$ or Lys ${ }^{40}$, the affinity significantly decreased to $\mathrm{IC}_{50}$ values of $48.1 \pm 5.1$ and $44.1 \pm 7.0 \mathrm{nmol} / \mathrm{L}$, respectively. Moreover, labeling of $\left[\mathrm{Lys}^{27}(\mathrm{Ahx}-\mathrm{DOTA})\right] \mathrm{Ex}(9-39) \mathrm{NH}_{2}$ with ${ }^{\text {nat }} \mathrm{Ga}$ resulted in further increase in $\mathrm{IC}_{50}$ values to $137.2 \pm 10.3 \mathrm{nmol} / \mathrm{L}$.

Because our previous work demonstrated sensitivity of sst2 receptor-specific antagonists to chelate modification (29), we tested whether another chelator would be more suitable. $\mathrm{Ex}(9-39) \mathrm{NH}_{2}$ was 
TABLE 1

GLP-1 Receptor $I_{50}$ Values for Different GLP-1 Receptor Agonists and Antagonists

\begin{tabular}{|c|c|c|c|}
\hline Compound & Ligand/metal complex & Human insulinoma (nM) & Rat insulinoma (nM) \\
\hline GLP-1(7-36) control & Ligand & $1.1 \pm 0.3$ & $0.8 \pm 0.1$ \\
\hline $\mathrm{Ex}(9-39) \mathrm{NH}_{2}$ & Ligand & $10.9 \pm 1.1$ & $3.9 \pm 1.7$ \\
\hline$\left[\mathrm{Nle}^{14}\right.$, Lys $\left.^{40}(\mathrm{Ahx}-\mathrm{DOTA}) \mathrm{NH}_{2}\right] \mathrm{Ex}-4$ & Ligand & $0.9 \pm 0.3$ & $0.5 \pm 0.2$ \\
\hline$\left[\right.$ Lys $\left.^{40}(\mathrm{Ahx}-\mathrm{DOTA}) \mathrm{NH}_{2}\right]-\mathrm{Ex}(9-39)$ & Ligand & $44.1 \pm 7.0$ & $8.5 \pm 3.0$ \\
\hline \multirow{2}{*}[\text{Lys}^{27}(\text{Ahx-DOTA})]{$-E x(9-39) \mathrm{NH}_{2}$} & Ligand & $48.1 \pm 5.1$ & $122.3 \pm 12.1$ \\
\hline & nat $G a$ & $137.2 \pm 10.3$ & $213.2 \pm 21.3$ \\
\hline \multirow[t]{2}{*}{ Lys $^{40}\left(\mathrm{NODAGA} \mathrm{NH}_{2}\right] \mathrm{Ex}(9-39)$} & Ligand & $29.7 \pm 10.7$ & $16.3 \pm 3.6$ \\
\hline & nat $\mathrm{Ga}$ & $46.7 \pm 16.3$ & $22.0 \pm 5.3$ \\
\hline \multirow[t]{2}{*}[\text{Lys}^{27}(\mathrm{NODAGA})]{$-\mathrm{Ex}(9-39) \mathrm{NH}_{2}$} & Ligand & $143.3 \pm 56.6$ & $81.0 \pm 8.9$ \\
\hline & nat $G a$ & $71.3 \pm 26.5$ & $46.7 \pm 9.3$ \\
\hline
\end{tabular}

functionalized with NODAGA at the same lysine positions. However, conjugation of NODAGA also led to a decrease in the affinity toward the hGLP-1 receptor with an $\mathrm{IC}_{50}$ of $143.3 \pm 5.1$ and $29.7 \pm 10.7 \mathrm{nmol} / \mathrm{L}$ for $\left[\mathrm{Lys}^{27}(\mathrm{NODAGA})\right] \mathrm{Ex}(9-39) \mathrm{NH}_{2}$ and $\left[\mathrm{Lys}^{40}(\mathrm{NODAGA}) \mathrm{NH}_{2}\right] \mathrm{Ex}(9-39)$, respectively, with $\left[\mathrm{Lys}^{40}\left(\mathrm{NODAGA}-{ }^{68} \mathrm{Ga}\right) \mathrm{NH}_{2}\right] \mathrm{Ex}(9-39)$ being the best hGLP-1 receptor binder among studied antagonists. Moreover, the results from Table 1 indicate that all tested GLP-1 antagonistic ligands had somewhat better affinity toward rat GLP-1, confirming the feasibility of using the rat insulinoma model for in vivo evaluation of tracer pharmacokinetics.

\section{Ex Vivo Biodistribution of Ex-4 and Ex(9-39) Derivatives, Labeled with ${ }^{68} \mathrm{Ga}$}

In vivo pharmacokinetics of GLP-1 receptor-targeting antagonistic tracers were evaluated in mice bearing rat Ins-1E xenografts at $1 \mathrm{~h}$ after injection (Tables 2 and 3). Biodistribution of the reference GLP-1 receptor agonist $\left[\mathrm{Nle}^{14}, \mathrm{Lys}^{40}\left(\mathrm{Ahx}-\mathrm{DOTA}-{ }^{68} \mathrm{Ga}\right) \mathrm{NH}_{2}\right] \mathrm{Ex}-4$ revealed high uptake in the tumor $(40.2 \pm 8.2 \% \mathrm{IA} / \mathrm{g})$ and pancreas $(12.5 \pm 2.2 \% \mathrm{IA} / \mathrm{g})$ and a tumor-to-blood ratio of 100.52 . Preinjection of the excess of $\operatorname{Ex}(9-39) \mathrm{NH}_{2}$ blocked uptake in the tumor and pancreas by $97 \%$. The kidney uptake was extremely high with $235.8 \pm 17.0 \% \mathrm{IA} / \mathrm{g}$, resulting in a tumor-to-kidney ratio of 0.17 (Tables 2 and 3).

The tumor uptake of the best antagonist $\left[\mathrm{Lys}^{40}\left(\mathrm{NODAGA}-{ }^{68} \mathrm{Ga}\right)\right.$ $\left.\mathrm{NH}_{2}\right] \operatorname{Ex}(9-39)$ was only $2.2 \pm 0.2 \% \mathrm{IA} / \mathrm{g}$; radioactivity in the pancreas and kidney was $1.0 \pm 0.1$ and $78.4 \pm 8.5 \% \mathrm{IA} / \mathrm{g}$, respectively; and ratios of tumor to blood and tumor to kidney were 7.33 and 0.03 , respectively. The other 2 antagonists, $\left[\mathrm{Lys}^{27}(\mathrm{Ahx}-\right.$ DOTA- $\left.\left.{ }^{68} \mathrm{Ga}\right)\right] \mathrm{Ex}(9-39) \mathrm{NH}_{2}$ and $\left[\mathrm{Lys}^{27}\right.$ (NODAGA- $\left.\left.{ }^{68} \mathrm{Ga}\right)\right] \mathrm{Ex}(9-$ 39) $\mathrm{NH}_{2}$, showed insignificant uptake in the tumor and pancreas

TABLE 2

Biodistribution of Ex-4 and Ex(9-39) Derivatives, Labeled with ${ }^{68} \mathrm{Ga}$ at 1 Hour After Injection $(\% \mathrm{IA} / \mathrm{g})$

\begin{tabular}{|c|c|c|c|c|c|}
\hline Organ & $\begin{array}{l}{\left[\mathrm{Nle}^{14}, \mathrm{Lys}^{40}(\mathrm{Ahx}-\right.} \\
\text { DOTA- } \\
\left.\left.{ }^{68} \mathrm{Ga}\right) \mathrm{NH}_{2}\right] \mathrm{Ex}-4\end{array}$ & $\begin{array}{c}{\left[\mathrm{Nle}^{14}, \text { Lys }^{40}(\mathrm{Ahx}-\right.} \\
\left.\text { DOTA-68 Ga) } \mathrm{NH}_{2}\right] \mathrm{Ex}-4 \\
\text { block* }^{*}\end{array}$ & 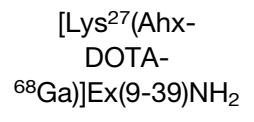 & $\begin{array}{l}{\left[\mathrm{Lys}^{27}(\mathrm{NODAGA}-\right.} \\
\left.\left.{ }^{68} \mathrm{Ga}\right)\right] \mathrm{Ex}(9-39) \mathrm{NH}_{2}\end{array}$ & $\begin{array}{l}{\left[\mathrm{Lys}^{40}(\mathrm{NODAGA}-\right.} \\
\left.\left.{ }^{68} \mathrm{Ga}\right) \mathrm{NH}_{2}\right] \mathrm{Ex}(9-39)\end{array}$ \\
\hline Blood & $0.4 \pm 0.1$ & $0.4 \pm 0.1$ & $0.2 \pm 0.1$ & $0.2 \pm 0.0$ & $0.3 \pm 0.0$ \\
\hline Heart & $0.2 \pm 0.0$ & $0.1 \pm 0.1$ & $0.1 \pm 0.0$ & $0.1 \pm 0.0$ & $0.1 \pm 0.0$ \\
\hline Lung & $5.0 \pm 0.9$ & $0.9 \pm 0.3$ & $0.0 \pm 0.0$ & $1.3 \pm 0.4$ & $1.4 \pm 0.4$ \\
\hline Spleen & $0.4 \pm 0.1$ & $0.5 \pm 0.2$ & $0.1 \pm 0.1$ & $0.25 \pm 0.04$ & $0.4 \pm 0.2$ \\
\hline Liver & $1.1 \pm 0.1$ & $0.9 \pm 0.2$ & $0.0 \pm 0.1$ & $0.6 \pm 0.2$ & $0.6 \pm 0.2$ \\
\hline Pancreas & $12.5 \pm 2.2$ & $0.4 \pm 0.1$ & $0.1 \pm 0.0$ & $0.5 \pm 0.1$ & $1.0 \pm 0.1$ \\
\hline Stomach & $2.8 \pm 0.3$ & $0.4 \pm 0.1$ & $0.2 \pm 0.0$ & $0.5 \pm 0.2$ & $0.7 \pm 0.3$ \\
\hline Intestine & $1.8 \pm 0.4$ & $0.4 \pm 0.1$ & $0.3 \pm 0.1$ & $0.5 \pm 0.2$ & $0.3 \pm 0.1$ \\
\hline Kidney & $235.8 \pm 17.0$ & $277.3 \pm 13.9$ & $113.8 \pm 23.8$ & $101.0 \pm 21.0$ & $78.4 \pm 8.5$ \\
\hline Adrenal & $6.5 \pm 1.4$ & $4.7 \pm 1.4$ & $2.0 \pm 0.5$ & $5.0 \pm 1.9$ & $6.0 \pm 4.5$ \\
\hline Muscle & $0.3 \pm 0.1$ & $0.3 \pm 0.1$ & $1.0 \pm 0.4$ & $0.3 \pm 0.1$ & $0.3 \pm 0.2$ \\
\hline Bone & $0.6 \pm 0.2$ & $0.5 \pm 0.2$ & $0.6 \pm 0.1$ & $0.2 \pm 0.1$ & $0.2 \pm 0.0$ \\
\hline Ins-1E & $40.2 \pm 8.2$ & $1.4 \pm 0.1$ & ND & $0.7 \pm 0.2$ & $2.2 \pm 0.2$ \\
\hline \multicolumn{6}{|c|}{$\begin{array}{l}\text { *80 nmol of Ex(9-39) were preinjected } 5 \text { min before tracer. } \\
\mathrm{ND}=\text { not determined. } \\
\text { Data are mean } \pm \mathrm{SD} \% \mathrm{IA} / \mathrm{g}, n=3-4\end{array}$} \\
\hline
\end{tabular}


TABLE 3

Tumor-to-Normal-Organ Ratios

\begin{tabular}{lcccc}
\hline Tumor-to-normal-organ ratios & Time $(\mathrm{h})$ & Tumor to blood & Tumor to muscle & Tumor to kidney \\
\hline$\left[\mathrm{Nle}^{14}, \mathrm{Lys}^{40}\left(\mathrm{Ahx}-\mathrm{DOTA}-{ }^{68} \mathrm{Ga}\right) \mathrm{NH}_{2}\right] \mathrm{Ex}-4$ & 1 & 100.52 & 134.01 & 0.17 \\
{$\left[\mathrm{Lys}^{27}\left(\mathrm{NODAGA}-{ }^{68} \mathrm{Ga}\right)\right] \mathrm{Ex}(9-39) \mathrm{NH}_{2}$} & 1 & 3.50 & 2.33 & 0.01 \\
{$\left[\mathrm{Lys}^{40}\left(\mathrm{NODAGA}-{ }^{68} \mathrm{Ga}\right) \mathrm{NH}_{2}\right] \mathrm{Ex}(9-39)$} & 1 & 7.33 & 7.33 & 0.03 \\
\hline
\end{tabular}

with comparably high accumulation of radioactivity in the kidney (Tables 2 and 3 ).

Figure 1 presents PET/CT images of mice injected with the reference GLP-1 receptor agonist $\left[\mathrm{Nle}^{14}\right.$,Lys ${ }^{40}$ (Ahx-DOTA- $\left.\left.{ }^{68} \mathrm{Ga}\right) \mathrm{NH}_{2}\right] \mathrm{Ex}-4$ and the best GLP-1 receptor antagonist $\left[\mathrm{Lys}^{40}\left(\mathrm{NODAGA}-{ }^{68} \mathrm{Ga}\right)\right.$ $\mathrm{NH}_{2}$ )] $\mathrm{Ex}(9-39)$. Both tracers detected GLP-1 receptor expression in Ins-1E xenografts; however, high radioactivity in the kidney

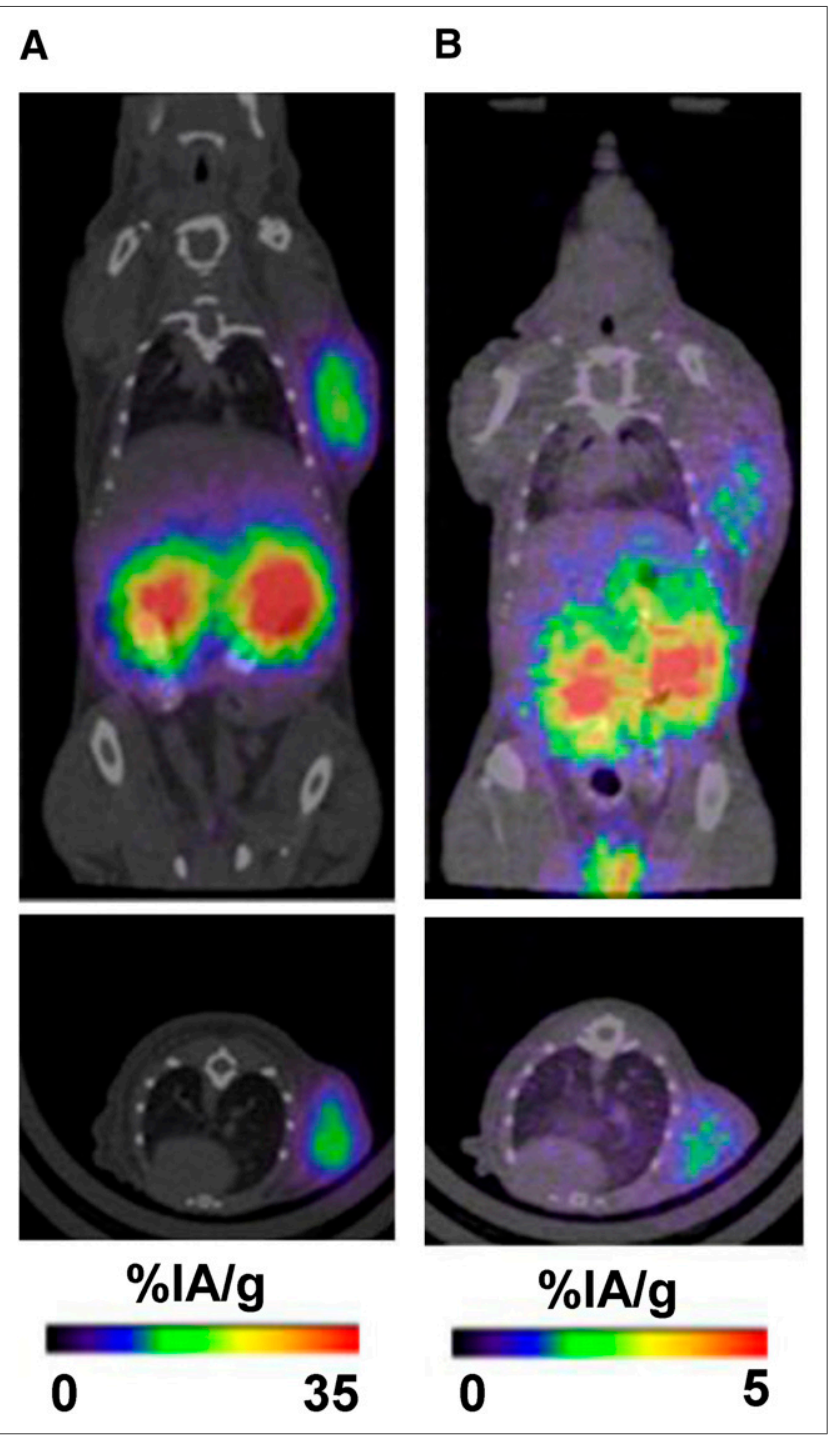

FIGURE 1. PET/CT imaging of GLP-1 receptor expression using radiolabeled agonist and antagonist. Coronal and transverse PET/CT images show biodistribution of $\left[\mathrm{Nle}^{14}, \mathrm{Lys}^{40}\left(\mathrm{Ahx}-\mathrm{DOTA}-{ }^{68} \mathrm{Ga}\right) \mathrm{NH}_{2}\right] \mathrm{Ex}-4 \mathrm{GLP}-1$ receptor agonist (A) and [Lys ${ }^{40}\left(\mathrm{NODAGA}-{ }^{68} \mathrm{Ga}^{2} \mathrm{NH}_{2}\right] \mathrm{Ex}(9-39)$ GLP-1 receptor antagonist $(B)$ in mice bearing Ins-1E tumors at $1 \mathrm{~h}$ after injection. prevented the detection of pancreas. Overall, because of higher tumor uptake, $\left[\mathrm{Nle}^{14}, \mathrm{Lys}^{40}\left(\mathrm{Ahx}-\mathrm{DOTA}{ }^{-68} \mathrm{Ga}\right) \mathrm{NH}_{2}\right.$ ]Ex-4 offers a much better image contrast.

\section{Ex Vivo Biodistribution of ${ }^{125}$-BH-Ex(9-39) $\mathrm{NH}_{2}$}

Previously, Reubi et al. reported that the antagonist ${ }^{125}$ I-BH-Ex (9-39) $\mathrm{NH}_{2}$ labeled at lysine 27 (lysine 19 when counted from 1-st amino acid) binds with high affinity to GLP-1 receptor-positive human and rat tissues in vitro and shows the same performance as the potent ${ }^{125}$ I-GLP-1(7-36) $\mathrm{NH}_{2}$ agonist (22). Therefore, we evaluated the biodistribution of this tracer in Ins-1E tumor-bearing mice.

In contrast to the above described ${ }^{68} \mathrm{Ga}$-labeled antagonists, ${ }^{125} \mathrm{I}-\mathrm{BH}-\mathrm{Ex}(9-39) \mathrm{NH}_{2}$ showed high uptake in Ins-1E tumor and pancreas at $1 \mathrm{~h}$ after injection, $42.5 \pm 8.1$ and $28.8 \pm 5.1 \% \mathrm{IA} / \mathrm{g}$, respectively, which was reduced at $4 \mathrm{~h}$ after injection to $19.8 \pm 4.3$ and $10.2 \pm 2.5 \% \mathrm{IA} / \mathrm{g}$, respectively (Table 4 ).

Most importantly, as we hypothesized, the kidney uptake of ${ }^{125} \mathrm{I}-\mathrm{BH}-\mathrm{Ex}(9-39) \mathrm{NH}_{2}$ was low, only $12.1 \pm 1.4 \% \mathrm{IA} / \mathrm{g}$ at $1 \mathrm{~h}$ after injection, and reduced to $4.2 \pm 0.7 \% \mathrm{IA} / \mathrm{g}$ at $4 \mathrm{~h}$ after injection, yielding tumor-to-kidney ratios of 3.51 and 4.81 at 1 and $4 \mathrm{~h}$ after injection, respectively (Tables 4 and 5). In comparison to the reference $\left[\mathrm{Nle}^{14}\right.$,Lys $\left.{ }^{40}\left(\mathrm{Ahx}-\mathrm{DOTA}-{ }^{68} \mathrm{Ga}\right) \mathrm{NH}_{2}\right] \mathrm{Ex}-4$ agonist, therefore, the tumor-to-kidney ratio of ${ }^{125} \mathrm{I}-\mathrm{BH}-\mathrm{Ex}(9-39) \mathrm{NH}_{2}$ was improved 20-fold (Tables 4 and 5).

Activity in the blood was somewhat higher than for the reference agonist, $2.4 \pm 0.5 \% \mathrm{IA} / \mathrm{g}$ at $1 \mathrm{~h}$ and $0.8 \pm 0.0 \% \mathrm{IA} / \mathrm{g}$ at $4 \mathrm{~h}$ after injection, with tumor-to-blood ratios of 17.62 and 24.13 at 1 and $4 \mathrm{~h}$ after injection, respectively. Tumor-to-muscle ratios were 193.11 at $1 \mathrm{~h}$ and 164.62 at $4 \mathrm{~h}$ after injection, also showing improvement, compared with $\left[\mathrm{Nle}^{14}{ }^{\mathrm{Lys}}{ }^{40}\left(\mathrm{Ahx}-\mathrm{DOTA}-{ }^{68} \mathrm{Ga}\right) \mathrm{NH}_{2}\right] \mathrm{Ex}-4$ (Table 5). Blocking experiments confirmed a specific, GLP-1 receptor-mediated uptake of ${ }^{125} \mathrm{I}-\mathrm{BH}-\mathrm{Ex}(9-39) \mathrm{NH}_{2}$ in Ins-1E tumor, pancreas, lung, and stomach (Table 4). Additionally, ${ }^{125} \mathrm{I}-\mathrm{BH}-\mathrm{Ex}(9-39) \mathrm{NH}_{2}$ had an uptake of $27.9 \pm 3.2 \% \mathrm{IA} / \mathrm{g}$ in the mouse liver at $1 \mathrm{~h}$, which was reduced to $9.3 \pm 1.3 \% \mathrm{IA} / \mathrm{g}$ at $4 \mathrm{~h}$ after injection (Table 4 ).

Because ${ }^{125} \mathrm{I}$ belongs to nonresidualizing radionuclides and free iodide can be released during in vivo deiodination of iodinated tracers, the accumulation of activity in the thyroid was also studied. At $1 \mathrm{~h}$ after ${ }^{125} \mathrm{I}-\mathrm{BH}-\mathrm{Ex}(9-39) \mathrm{NH}_{2}$ injection, $2.45 \pm 0.56 \% \mathrm{IA} / \mathrm{g}$ was accumulated in the thyroid tissue (Table 4). Blocking the sodium iodide symporter with irenat (sodium perchlorate) resulted in a more than $80 \%$ reduction of thyroid uptake. Biodistribution at $24 \mathrm{~h}$ after injection revealed that ${ }^{125} \mathrm{I}-\mathrm{BH}-\mathrm{Ex}(9-39) \mathrm{NH}_{2}$ was almost completely cleared from the body, with $0.02 \pm 0.01 \% \mathrm{IA} / \mathrm{g}$ remaining in the blood and $0.69 \pm 0.25 \% \mathrm{IA} / \mathrm{g}$ remaining in the tumor (Table 4).

\section{Ex Vivo Autoradiography}

Parts of Ins-1E tumor, pancreas, and kidney at $1 \mathrm{~h}$ after injection of ${ }^{125} \mathrm{I}-\mathrm{BH}-\mathrm{Ex}(9-39) \mathrm{NH}_{2}$ were frozen and processed for autoradiography. 
TABLE 4

Biodistribution of ${ }^{125} \mathrm{I}-\mathrm{BH}-\mathrm{Ex}(9-39) \mathrm{NH}_{2}$ in Mice Bearing Ins-1E Tumors

\begin{tabular}{|c|c|c|c|c|c|}
\hline Organ & $1 \mathrm{~h}$ & 1-h Irenat* & 1-h block ${ }^{\dagger}$ & $4 \mathrm{~h}$ & $24 \mathrm{~h}$ \\
\hline Blood & $2.41 \pm 0.52$ & $2.33 \pm 0.39$ & $2.75 \pm 0.03$ & $0.82 \pm 0.02$ & $0.02 \pm 0.01$ \\
\hline Heart & $1.11 \pm 0.20$ & $1.03 \pm 0.19$ & $0.69 \pm 0.02$ & $0.44 \pm 0.09$ & $0.01 \pm 0.00$ \\
\hline Lung & $19.94 \pm 2.60$ & $31.87 \pm 2.92$ & $1.49 \pm 0.34$ & $11.85 \pm 1.76$ & $0.14 \pm 0.06$ \\
\hline Spleen & $0.97 \pm 0.12$ & $0.78 \pm 0.14$ & $0.66 \pm 0.08$ & $0.29 \pm 0.05$ & $0.02 \pm 0.01$ \\
\hline Liver & $27.95 \pm 3.20$ & $25.03 \pm 1.39$ & $25.32 \pm 2.82$ & $9.30 \pm 1.30$ & $0.13 \pm 0.01$ \\
\hline Pancreas & $28.85 \pm 5.10$ & $27.47 \pm 9.29$ & $0.72 \pm 0.03$ & $10.16 \pm 2.50$ & $0.16 \pm 0.09$ \\
\hline Stomach & $7.32 \pm 2.66$ & $8.12 \pm 3.60$ & $1.10 \pm 0.20$ & $2.79 \pm 0.21$ & $0.07 \pm 0.05$ \\
\hline Intestine & $3.67 \pm 0.68$ & $3.94 \pm 1.05$ & $3.24 \pm 2.09$ & $1.43 \pm 0.13$ & $0.05 \pm 0.02$ \\
\hline Kidney & $12.12 \pm 1.41$ & $13.53 \pm 2.71$ & $22.06 \pm 1.60$ & $4.15 \pm 0.70$ & $0.14 \pm 0.04$ \\
\hline Adrenals & $0.84 \pm 0.38$ & $0.74 \pm 0.00$ & $1.04 \pm 0.01$ & $0.32 \pm 0.16$ & ND \\
\hline Muscle & $0.22 \pm 0.04$ & $0.21 \pm 0.04$ & $0.22 \pm 0.02$ & $0.12 \pm 0.05$ & $0.01 \pm 0.00$ \\
\hline Bone & $0.31 \pm 0.05$ & 0.27 & $0.36 \pm 0.03$ & $0.15 \pm 0.06$ & $0.02 \pm 0.02$ \\
\hline Ins-1E & $42.46 \pm 8.05$ & $40.53 \pm 8.19$ & $2.78 \pm 0.22$ & $19.76 \pm 4.26$ & $0.69 \pm 0.25$ \\
\hline Thyroid ${ }^{\ddagger}$ & $2.45 \pm 0.56$ & $0.42 \pm 0.08$ & & & \\
\hline
\end{tabular}

${ }^{*}$ To block sodium iodide symporter, irenat $(120 \mathrm{mg} / \mathrm{kg})$ was injected intravenously before tracer injection.

† $80 \mathrm{nmol}$ of Ex(9-39) were injected before tracer.

†Thyroid was removed together with trachea, and total mass ( $60 \mathrm{mg})$ was used to calculate $\% \mathrm{IA} / \mathrm{g}$ (actual mass of thyroid is several mg).

$\mathrm{ND}=$ not detected.

Data are mean $\pm \mathrm{SD} \% \mathrm{IA} / \mathrm{g}, n=3$.

The digital autoradiography images shown in Figure 2 demonstrate that tracer accumulation in the kidney was significantly lower than in the pancreas and tumor, providing further evidence for the dramatically improved tumor-to-kidney ratios of ${ }^{125} \mathrm{I}-\mathrm{BH}-\mathrm{Ex}(9-39) \mathrm{NH}_{2}$ antagonist (Fig. 2). Additionally, the pancreas image shows heterogeneous distribution of the radioactivity. This is in agreement with the previously published data demonstrating that GLP-1 receptor levels in pancreatic islets are higher than in acini (1). Because the autoradiography was done on a thin section $(10 \mu \mathrm{m})$ only 1 islet (red spot) is visible.

\section{DISCUSSION}

GLP-1 is a key hormone of the incretin receptor family, a class B G-protein-coupled receptor. The GLP-1 receptors are of interest because of their high expression in more than $90 \%$ of benign insulinomas but also in gastrinomas and phaeochromocytomas (1).

Therefore, strong efforts have been made to develop imaging agents for optical/fluorescence imaging (2), MRI (14), bimodal imaging (3), and in particular SPECT $(4,7,30)$ and PET (8-13), not only for insulinoma localization but also for $\beta$-cell mass determination in diabetic animals and patients.
Despite these efforts and successful translation of agonistic SPECT $(4,5,7)$ and PET $(8,13,15)$ tracers into the clinic, further improvements may be required to lower the extremely high kidney uptake of radiometal-based peptides, which complicates the detection of insulinomas in the head and tail of the pancreas and poses a potential radiation safety hazard. In addition, the release of insulin stimulated by low-specific-activity agonists and concomitant hypoglycemia complicates clinical studies and could be a safety issue. We therefore aimed to develop suitable radiolabeled antagonists, which were shown within other G-protein-coupled receptor families to target more receptor binding sites than agonists.

Autoradiographic studies were used to determine $\mathrm{IC}_{50}$ values on human tumor tissue. When ${ }^{125} \mathrm{I}$-GLP-1(7-36) $\mathrm{NH}_{2}$ was used as a radioligand, the lowest $\mathrm{IC}_{50}$ values were found for the 2 agonists $\left[\mathrm{Nle}^{14}\right.$, Lys $\left.^{40}(\mathrm{Ahx}-\mathrm{DOTA}) \mathrm{NH}_{2}\right] \mathrm{Ex}-4(0.9 \pm 0.3 \mathrm{nmol} / \mathrm{L})$ and GLP-1(7-36) $\mathrm{NH}_{2}(1.1 \pm 0.3 \mathrm{nmol} / \mathrm{L}) . \operatorname{Ex}(9-39) \mathrm{NH}_{2}$ antagonist exhibited a high receptor affinity, but on conjugation of a radiometalDOTA or -NODAGA complex the affinity dropped considerably to $\mathrm{IC}_{50}$ values between 30 and $140 \mathrm{nmol} / \mathrm{L}$. Other than expected, the modification at $\mathrm{Lys}^{27}$ did not result in good binders. In contrast to our expectation, the Lys ${ }^{27}$ position appeared to be even more vulnerable than Lys $^{40}$ to chelate modification.

TABLE 5

125I-BH-Ex(9-39) $\mathrm{NH}_{2}$ Tumor-to-Normal-Organ Ratios

\begin{tabular}{lcccc}
\hline Tumor-to-normal-organ ratios & Time & Tumor to blood & Tumor to muscle & Tumor to kidney \\
\hline 125 I-BH-Ex(9-39) $\mathrm{NH}_{2}$ & $1 \mathrm{~h}$ & 17.62 & 193.11 & 3.51 \\
$125 \mathrm{I}-\mathrm{BH}-\mathrm{Ex}(9-39) \mathrm{NH}_{2}$ & $4 \mathrm{~h}$ & 24.13 & 164.62 & 4.81 \\
\hline
\end{tabular}




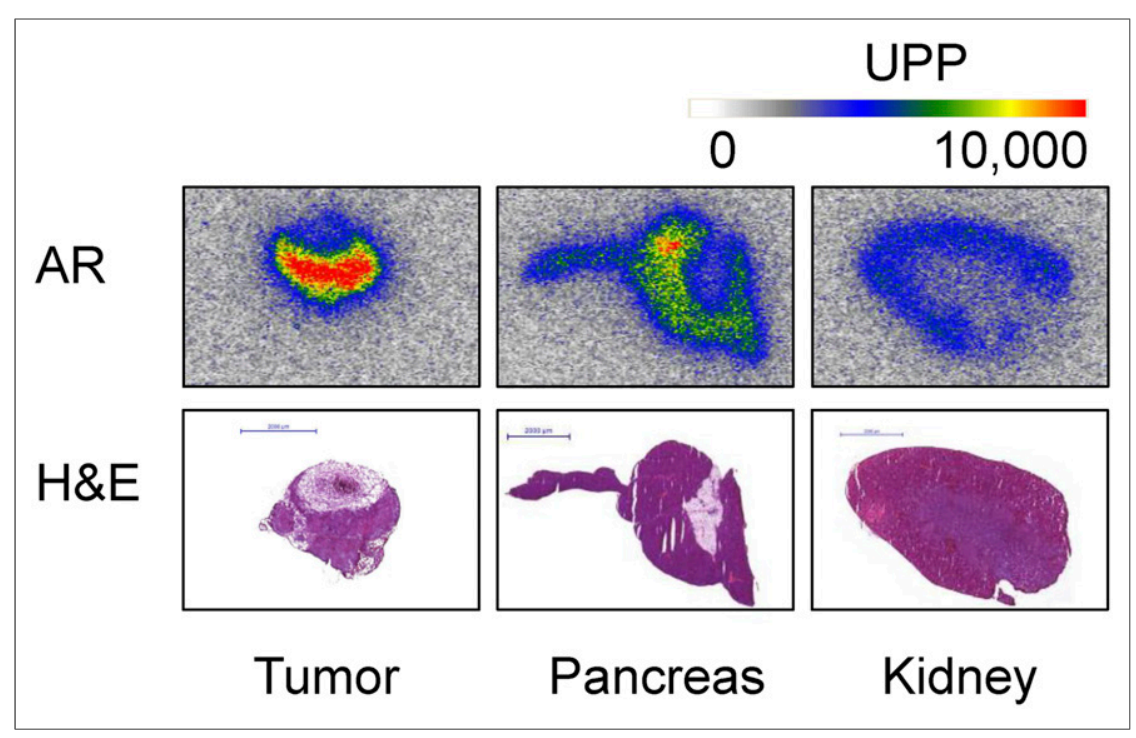

FIGURE 2. EX vivo autoradiography. Digital autoradiography images show lower uptake of 125/-BH-Ex(9-39) $\mathrm{NH}_{2}$ in kidney in comparison to Ins-1E tumor and pancreas $1 \mathrm{~h}$ after injection. $\mathrm{AR}=$ autoradiography image; $\mathrm{H} \& \mathrm{E}=$ image of the hematoxylin and eosin staining; UPP = units per pixel.

$\left[\mathrm{Lys}^{40}\left(\mathrm{NODAGA}-{ }^{\text {nat }} \mathrm{Ga}\right) \mathrm{NH}_{2}\right] \mathrm{Ex}(9-39)$ was the best GLP-1 receptor binder among studied antagonists.

$\left[\mathrm{Nle}^{14}{ }_{\text {Lys }}{ }^{40}\right.$ (Ahx-DOTA- $\left.\left.{ }^{68} \mathrm{Ga}\right) \mathrm{NH}_{2}\right] \mathrm{Ex}-4$ reference agonist showed fast blood clearance and high $(40.2 \pm 8.2 \% \mathrm{IA} / \mathrm{g})$ and specific tumor uptake as shown by the blocking experiment. In addition, the lung uptake was high because of high GLP-1 receptor expression in mouse lungs. There is not much concern in regard to human application because the human lung has a much lower expression of GLP-1 receptors (1). In accordance with earlier studies using metallic radionuclides, the kidney uptake was extremely high with $235.8 \pm 17.0 \% \mathrm{IA} / \mathrm{g}$, resulting in a very low tumor-to-kidney ratio of only 0.17 at $1 \mathrm{~h}$ after injection. Because of the much lower affinity of $\left[\mathrm{Lys}^{40}\left(\mathrm{NODAGA}-{ }^{68} \mathrm{Ga}\right) \mathrm{NH}_{2}\right] \mathrm{Ex}(9$ 39 ) antagonist, the tumor uptake was about 20 -fold lower.

The other 2 antagonists showed negligible tumor uptake. On the basis of these results antagonistic tracers, labeled with ${ }^{68} \mathrm{Ga}$, independent of the site of modification, appear to be not suitable for imaging of the GLP-1 receptor expression in vivo.

We then moved to $\left[\mathrm{Lys}^{27}\left({ }^{125} \mathrm{I}-\mathrm{BH}\right)\right] \mathrm{Ex}(9-39) \mathrm{NH}_{2}$ and compared the biodistribution data with the radiometal-labeled peptides. The expectation was to have a distinctly lower kidney uptake due to the nonresidualizing properties of the ${ }^{125} \mathrm{I}$ label. Indeed, ${ }^{125} \mathrm{I}-\mathrm{BH}-\mathrm{Ex}(9-39) \mathrm{NH}_{2}$ showed different pharmacokinetics. The tumor uptake at $1 \mathrm{~h}$ after injection was high and equal to the one of agonist, but the kidney uptake was $95 \%$ lower, resulting in a tumor-to-kidney ratio of 3.51 , a 20-fold ratio improvement when compared with the agonist $\left.\left[\mathrm{Nle}^{14}, \mathrm{Lys}^{40}\left(\mathrm{Ahx}-\mathrm{DOTA}-{ }^{68} \mathrm{Ga}\right) \mathrm{NH}_{2}\right)\right] \mathrm{Ex}-4$. A preinjected excess of $\mathrm{Ex}(9-39) \mathrm{NH}_{2}$ blocked the tumor uptake of the radioligand by about $95 \%$, demonstrating that the tumor uptake was specific and receptor-mediated. Uptake in the lung and pancreas was high and receptor-mediated as well.

Additionally, radioactivity was detected in the thyroid, indicating that free iodide was released after in vivo deiodination of ${ }^{125} \mathrm{I}-\mathrm{BH}-\mathrm{Ex}(9-39) \mathrm{NH}_{2}$. However, thyroid uptake of iodinated tracers can be effectively blocked by irenat, the competitive inhibitor of the sodium iodide symporter $(31,32)$. In our model, blocking of the sodium iodide symporter by irenat reduced the thyroid uptake by more than $80 \%$.

Not unexpectedly for antagonists that do not internalize, the washout from receptorpositive tissues was relatively fast. At $4 \mathrm{~h}$, tumor activity dropped $50 \%$ but the tumorto-kidney ratio increased to 4.81 as the washout from the kidney was distinctly faster. After $24 \mathrm{~h}$, the radioactivity in the animal had cleared substantially, which predicts acceptable radiation dosimetry on clinical translation of an ${ }^{124} \mathrm{I}$-labeled congener.

Among published GLP-1 receptor tracers, the fluorinated agonist $\left[{ }^{18} \mathrm{~F}\right] \mathrm{FBEM}-\left[\mathrm{Cys}^{40}\right]-$ exendin-4 showed a comparable tumor-tokidney ratio (4.94 at $2 \mathrm{~h}$ after injection) and in addition it had a better tumor-to-liver ratio than the iodinated tracer (12). This might suggest that fluorinated GLP-1 receptor antagonists could be worthwhile to study. However, the iodinated tracers are more attractive because of the potential theranostic application.

Several approaches for the reduction of kidney uptake of radiolabeled tracers have been described in the literature, including pretargeting approaches (33) and competitive inhibition of proximal tubular reabsorption by infusion of amino acids (25). Radioiodination can serve as an alternative approach to prevent high kidney retention of the peptide tracers. In addition to improving the tumor-to-kidney ratio, radioiodinated GLP-1 receptor antagonists would not induce the insulin secretion and subsequent hypoglycemia in patients. Furthermore, an iodination approach can be applied to the other large peptide tracers, such as gastric inhibitory peptide receptor targeting peptides, which also suffer from high kidney uptake, when labeled with radiometals.

\section{CONCLUSION}

Our results demonstrate that ${ }^{68} \mathrm{Ga}$-labeled $\mathrm{Ex}(9-39) \mathrm{NH}_{2}$ antagonists, independent of the site of modification, are not suitable for in vivo imaging of GLP-1 receptor expression because of low affinity and insignificant tumor uptake. On the other hand, ${ }^{125} \mathrm{I}-$ Bolton-Hunter-labeled $\operatorname{Ex}(9-39) \mathrm{NH}_{2}$ antagonist showed favorable biodistribution, with tumor uptake comparable to the radiolabeled agonists and a 20-fold-improved tumor-to-kidney ratio. Because mass effects will not change the pharmacology of radioiodinated tracers, we concluded that ${ }^{124} \mathrm{I}-/{ }^{131} \mathrm{I}-\mathrm{BH}-\mathrm{Ex}(9-39) \mathrm{NH}_{2}$ should be promising candidates for theranostic approaches.

\section{DISCLOSURE}

The costs of publication of this article were defrayed in part by the payment of page charges. Therefore, and solely to indicate this fact, this article is hereby marked "advertisement" in accordance with 18 USC section 1734. This work was supported by DKTK and SFB850 (project Z2). No other potential conflict of interest relevant to this article was reported.

\section{ACKNOWLEDGMENTS}

We acknowledge Dr. Günter Päth for providing Ins-1E cells. 


\section{REFERENCES}

1. Körner M, Stockli M, Waser B, Reubi JC. GLP-1 receptor expression in human tumors and human normal tissues: potential for in vivo targeting. J Nucl Med. 2007;48:736-743.

2. Reiner T, Thurber G, Gaglia J, et al. Accurate measurement of pancreatic islet beta-cell mass using a second-generation fluorescent exendin-4 analog. Proc Natl Acad Sci USA. 2011;108:12815-12820.

3. Brand C, Abdel-Atti D, Zhang Y, et al. In vivo imaging of GLP-1R with a targeted bimodal PET/fluorescence imaging agent. Bioconjug Chem. 2014;25:1323-1330.

4. Wild D, Macke H, Christ E, Gloor B, Reubi JC. Glucagon-like peptide 1-receptor scans to localize occult insulinomas. N Engl J Med. 2008;359:766-768.

5. Christ E, Wild D, Forrer F, et al. Glucagon-like peptide-1 receptor imaging for localization of insulinomas. J Clin Endocrinol Metab. 2009;94:4398-4405.

6. Brom M, Joosten L, Oyen WJ, Gotthardt M, Boerman OC. Radiolabeled GLP-1 analogues for in vivo targeting of insulinomas. Contrast Media Mol Imaging. 2012;7:160-166.

7. Sowa-Staszczak A, Pach D, Mikolajczak R, et al. Glucagon-like peptide-1 receptor imaging with [Lys40(Ahx-HYNIC- ${ }^{99 m}$ Tc/EDDA)NH2]-exendin-4 for the detection of insulinoma. Eur J Nucl Med Mol Imaging. 2013;40:524-531.

8. Eriksson O, Velikyan I, Selvaraju RK, et al. Detection of metastatic insulinoma by positron emission tomography with $\left[{ }^{68} \mathrm{Ga}\right]$ exendin-4: a case report. J Clin Endocrinol Metab. 2014;99:1519-1524.

9. Wu Z, Liu S, Nair I, et al. ${ }^{64} \mathrm{Cu}$ labeled sarcophagine exendin-4 for microPET imaging of glucagon like peptide-1 receptor expression. Theranostics. 2014;4:770-777.

10. Wang Y, Lim K, Normandin M, Zhao X, Cline GW, Ding YS. Synthesis and evaluation of $\left[{ }^{18} \mathrm{~F}\right]$ exendin (9-39) as a potential biomarker to measure pancreatic beta-cell mass. Nucl Med Biol. 2012;39:167-176.

11. Gao H, Niu G, Yang M, et al. PET of insulinoma using ${ }^{18}$ F-FBEM-EM3106B, a new GLP-1 analogue. Mol Pharm. 2011;8:1775-1782.

12. Kiesewetter DO, Gao H, Ma Y, et al. ${ }^{18}$ F-radiolabeled analogs of exendin- 4 for PET imaging of GLP-1 in insulinoma. Eur J Nucl Med Mol Imaging. 2012;39: 463-473.

13. Luo Y, Yu M, Pan Q, et al. ${ }^{68}$ Ga-NOTA-exendin-4 PET/CT in detection of occult insulinoma and evaluation of physiological uptake. Eur J Nucl Med Mol Imaging. 2015;42:531-532.

14. Vinet L, Lamprianou S, Babic A, et al. Targeting GLP-1 receptors for repeated magnetic resonance imaging differentiates graded losses of pancreatic beta cells in mice. Diabetologia. 2015;58:304-312.

15. Antwi K, Fani M, Nicolas G, et al. Localization of hidden insulinomas with ${ }^{68}$ Ga-DOTA-Exendin-4 PET/CT: a pilot study. J Nucl Med. 2015;56:1075-1078.

16. Ginj M, Zhang H, Waser B, et al. Radiolabeled somatostatin receptor antagonists are preferable to agonists for in vivo peptide receptor targeting of tumors. Proc Natl Acad Sci USA. 2006;103:16436-16441.

17. Abiraj K, Mansi R, Tamma ML, et al. Bombesin antagonist-based radioligands for translational nuclear imaging of gastrin-releasing peptide receptor-positive tumors. J Nucl Med. 2011;52:1970-1978.
18. Wieser G, Mansi R, Grosu AL, et al. Positron emission tomography (PET) imaging of prostate cancer with a gastrin releasing peptide receptor antagonist-from mice to men. Theranostics. 2014;4:412-419.

19. Bodei L, Ferrari M, Nunn AD, et al. ${ }^{177} \mathrm{Lu}-\mathrm{AMBA}$ bombesin analogue in hormone refractory prostate cancer patients: a phase I escalation study with single-cycle administrations [abstract]. Eur J Nucl Med Mol Imaging. 2007;34(suppl 2):S221.

20. Göke R, Fehmann HC, Linn T, et al. Exendin-4 is a high potency agonist and truncated exendin-(9-39)-amide an antagonist at the glucagon-like peptide 1-(7-36)-amide receptor of insulin-secreting beta-cells. J Biol Chem. 1993;268:19650-19655.

21. Mukai E, Toyoda K, Kimura H, et al. GLP-1 receptor antagonist as a potential probe for pancreatic beta-cell imaging. Biochem Biophys Res Commun. 2009; 389:523-526.

22. Waser B, Reubi JC. Radiolabeled GLP-1 receptor antagonist binds to GLP-1 receptorexpressing human tissues. Eur J Nucl Med Mol Imaging. 2014;41:1166-1171.

23. Press OW, Shan D, Howell-Clark J, et al. Comparative metabolism and retention of iodine-125, yttrium-90, and indium-111 radioimmunoconjugates by cancer cells. Cancer Res. 1996;56:2123-2129.

24. Shih LB, Thorpe SR, Griffiths GL, et al. The processing and fate of antibodies and their radiolabels bound to the surface of tumor cells in vitro: a comparison of nine radiolabels. J Nucl Med. 1994;35:899-908.

25. Vegt E, de Jong M, Wetzels JF, et al. Renal toxicity of radiolabeled peptides and antibody fragments: mechanisms, impact on radionuclide therapy, and strategies for prevention. J Nucl Med. 2010;51:1049-1058.

26. Merglen A, Theander S, Rubi B, Chaffard G, Wollheim CB, Maechler P. Glucose sensitivity and metabolism-secretion coupling studied during two-year continuous culture in INS-1E insulinoma cells. Endocrinology. 2004;145:667-678.

27. Mikkola K, Yim CB, Fagerholm V, et al. ${ }^{64} \mathrm{Cu}$ - and ${ }^{68} \mathrm{Ga}$-labeled [Nle(14),Lys (40)(Ahx-NODAGA)NH2]-exendin-4 for pancreatic beta cell imaging in rats. Mol Imaging Biol. 2014;16:255-263.

28. Rylova SN, Barnucz E, Fani M, et al. Does imaging alphavbeta3 integrin expression with PET detect changes in angiogenesis during bevacizumab therapy? J Nucl Med. 2014;55:1878-1884.

29. Fani M, Del Pozzo L, Abiraj K, et al. PET of somatostatin receptor-positive tumors using ${ }^{64} \mathrm{Cu}$ - and ${ }^{68} \mathrm{Ga}$-somatostatin antagonists: the chelate makes the difference. J Nucl Med. 2011;52:1110-1118.

30. Gotthardt M, Fischer M, Naeher I, et al. Use of the incretin hormone glucagonlike peptide-1 (GLP-1) for the detection of insulinomas: initial experimental results. Eur J Nucl Med Mol Imaging. 2002;29:597-606.

31. Zechmann CM, Afshar-Oromieh A, Armor T, et al. Radiation dosimetry and first therapy results with a ${ }^{124} \mathrm{I} /{ }^{131} \mathrm{I}$-labeled small molecule (MIP-1095) targeting PSMA for prostate cancer therapy. Eur J Nucl Med Mol Imaging. 2014;41:1280-1292.

32. Mier W, Kratochwil C, Hassel JC, et al. Radiopharmaceutical therapy of patients with metastasized melanoma with the melanin-binding benzamide ${ }^{131}$ I-BA52. J Nucl Med. 2014;55:9-14.

33. van Duijnhoven SM, Rossin R, van den Bosch SM, Wheatcroft MP, Hudson PJ, Robillard MS. Diabody pretargeting with click chemistry in vivo. J Nucl Med. 2015;56:1422-1428. 